\title{
Epistemological Views Analyses of Plastic Fabrics Artistic Iconography in Sub-Saharan Africa
}

\author{
Suh Hillary Sama \\ Department of History and Archeology, University of Dschang, West Region, Cameroon
}

Email address:

Samsuh200@yahoo.com

\section{To cite this article:}

Suh Hillary Sama. Epistemological Views Analyses of Plastic Fabrics Artistic Iconography in Sub-Saharan Africa. History Research. Vol. 7, No. 2, 2019, pp. 65-76. doi: 10.11648/j.history.20190702.16

Received: July 8, 2019; Accepted: October 26, 2019; Published: December 4, 2019

\begin{abstract}
This piece of work on Sub-Saharan Africa Iconography expresses as objective the idealistic fabrics that enrich the cultural background that emanated or began from ancient Egypt during the prehistoric times and meaning images in Greek language. It was used by an artist or artists to covey particular meanings, this later move in to Greece and to other parts of the world. This has become very important to Sub-Sahara Africa like Egypt, Libya (Nubian), Senegal, Ghana (Gold Coast), Benin (Dahomey) Kenya, South Africa, Mali, Algeria, Chad, Nigeria, Cameroon, Zimbabwe and others. The breaking down of these wealthy resources as objects goes a long way to illustrate the quality substances and technical sense or knowledge in manufacturing and constructing. It should be noted that this followed a methodology, with the passing of time these Sub Sahara African Iconography has been transform to an extend gaining admirable and enjoyable plastics characteristics with a lot of meaningful interpretation from the artistic works. As a result, Sub-Saharan Africa Iconography embodied some aspects like The United States of America constructed structures in University of Dschang, Ekok and Bonaberi Bridges as Architectural Developments, the Nok-Head and carved Head of Juju Nkwifon in the Bafut palace as Sculptural advancements, Ceremonial Grassfields and Igbo Traditional Dress and Painting, a Queen Mother Head in Bafut as indicated signs of progress in Paintings, also the Egyptian hieroglyphics developed, the Shumum of the Bamoun kingdom also developed involving others like the Senegalese Wolof and kenyan Swahilis as Writings skills, has been crackdown through explanations and are very significant. They are very rich and these have given birth and rebirth to Sub Sahara African civilizations. Therefore, our notion is also to make known and comprehend that all that originated from Sub-Saharan Africa and left, returned in several folds. All has helped to build the Society. This piece of work has been developed with the help of documents, artistic pictures from Snapshuts and museum, interviews and facts from internet sources.
\end{abstract}

Keywords: Sub-Saharan Africa, Iconography, Enrich, Cultural, Background, Plastics, Civilization, Build, Society

\section{Introduction}

According to Cheikh Anta Diop, Africa is blessed with a "decent cultural background". The Cailo Museums collection of $19^{\text {th }}$ Century, Sub-Saharan Africa art offers valuable insight of Africa artistic expression in the variety of their form, functions and culture of origin. [13] Sub-Saharan region has been heritage of these beauties. A majority of the objects comes from West Africa, with a focus on the numerous culture of Nigeria. Benin (formerly Dahomey) and the Cameroon grassfields. [15] The rest are from the Equatorial Central region of the continent, located mainly in the modern state of Zaire. Made from different types of materials, the objects in this collection bear evidence of uses in a variety of contexts both religion and secular. There are figures from personal or family shrines, such as Igbo Ikenga shrine figures complemented by those used in community shrines such as the Mambila bark painting. There are examples like the exquisite beaded bowl figure from Kom kingdom of the Cameroon grassfields, used by royalty to hold kola nuts for their guest. The collection also includes a wide variety of masks and costumes danced in masquerades, which carries religious and cultural significance for participants including the audience. [38, 23] The works demonstrate important aspects of the world wide and aesthetic values of their culture of origins. Sub Saharan Africa and Saharan region in particular also exert some textiles works such as the Adire textile company Nigeria. 
[11] Some African clothes printing; Ndinkra, Adire robes of Nigerian women, Asafor, AsoOke, Bokolan, Ewe Francophones, Indigo, Kente, Kuba all ties with iconography. Sub-Saharan Africa is rich in all domains "Africa in miniature" thus it iconography show proof. Therefore, the questions that need an answer is, what are some of the different Iconography presentations and what is the importance of this iconographical works. To answer these questions it will be interesting to examine the following key aspects as seen below. Some Definitions, Evolutionary Meaning and Origin of Iconography in Sub-Saharan Africa, Architecture and Sculpture in the Sub Saharan Region, Painting and Writing in Sub-Saharan Region, Importance of Iconography in Sub-Saharan Africa.

\section{Method}

\subsection{Some Definitions, Evolutionary Meaning and Origin of Iconography in Sub-Saharan Africa}

\subsubsection{Some Definitions}

Iconography as examine by collaborative International Dictionary of English V.O. 48:

i. Iconography

II co*nog "ra*phy\, n. [Gr.? A sketch or descriptionikw n an image+? Of describe: cf.f. Iconography][39]

a) The art

The Art or representation by pictures or images: The description or study of portraiture or representation, as of persons; as the iconography of the ancients [1913 Webster] [39].

b) In General.

The study of representative of art in general. [1913Webster] Christian iconography, the study of the representations in art of the Deity, the persons of the Trinity, angels, saints, virtues vices etc. [1913 Webster]. Iconography-word net (r) 2.0 (August 2003):

Iconography, $\underline{\mathrm{n}}$ : the images and symbolic representations that are traditionally associated with a person or a subject; "religious iconography"; "the propagandistic iconography of a despot". [37]

Iconography-moby Thesaurus II by Grady ward, I.D: 50 moby Thesaurus words for "iconography": alphabet, art, blueprint, charactering, characterization, dance notation, delineation, demonstration, depiction, figuration, hierographic, ideogram, locography, map, musical notation, notation, pictogram, picturization, printing, projection, realization, rendering, rendition, representation, schema, score script, syllabery, symbol, tablature and writing. [21, 39]

ii. Images Representation

Iconography is a visual representation (of an object or person or scene or abstraction) produced on a surface. "They showed to us the pictures of their wedding or dance" a movie is a series of images projected so rapidly that the eye integrates them. [20]

a) Subject Description

The branch of study concerned with the form and representation of the subject, the science of description of subject-master and symbolism in the figurative Arts.

b) Symbolism

A generally recognized set of subjects that are considered to symbolize a particular movement, genre, flag etc.

c) Portraits on Coins

Until the mid- $19^{\text {th }}$ century, the branch of study concerned with the identification or collection representation of portraits. For example, those on coins. [24]

d) co.nog.ra.phy

General characteristics of African architecture reflects the interaction of environmental factors - such as natural resources, climate, and vegetation - with the economies and population densities of the continent's various regions. As stone is the most durable of building materials, some ancient stone structures survive, while other materials have succumbed to rain, rot, or termites. [12] Stone-walled kraals from early Sotho and Tswana settlements (South Africa and Botswana) and stone-lined pit circles with sunken kraals for pygmy cattle (Zimbabwe) have been the subject of archaeological study. Stone-corbeled shelters and circular huts with thatched roofs were also recorded in the 20th century among the southern Sotho. Rectangular and circular stone farmhouses, unusual in being two stories, have been built by the Tigre of Eritrea and Sudan for centuries, while in Niger some Tuareg build square houses in stone. The Statutes in one of the palaces in the grassfields at Bafoussam.

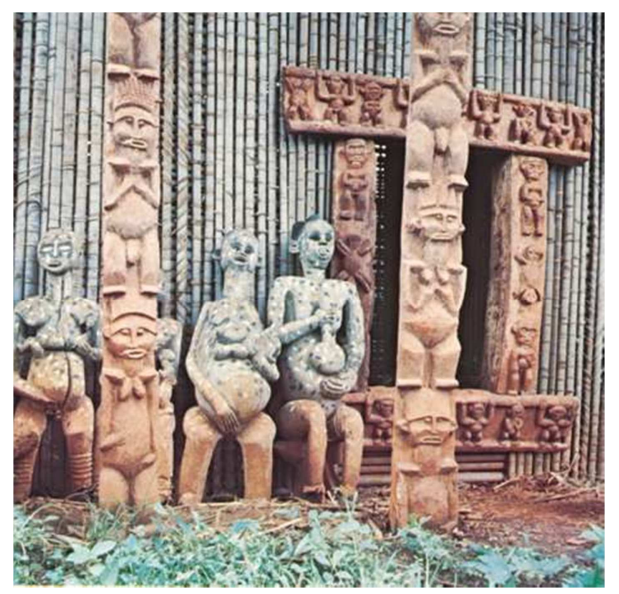

Figures 1. Statute of some ancestor in Chiefdom [14].

Source: Paul Oliver, JanetB. Hess, Africa Architecture In https://www.britannica.com/art/Africa-architecture.18mars 2018 (consulted 09/10/2019). [29]

Initially, much of such exceptions apart, the overwhelming majority of Sub Saharan Africa's thousands of peoples in rural areas build in grasses, wood, and clay. Because of the impermanence of many of these materials, existing buildings, though based on forms many centuries old, are of relatively recent date. Bamboo construction reached its apogee in the tall houses of the Bamileke and other peoples of western Cameroon, who constructed steep prefabricated pyramidal roofs raised on platforms with verandas; the whole structure frequently reached 33 feet (10 metres) or more, with male 
and female ancestor figures often flanking the doors. [26, 16] e) Picture

Picture illustration of a subject. Other Examples of Igbo Art, prior to British colonialism, the Igbo were a fragmented and diverse group, a quality reflected in its artistic styles. Besides the bronze artifacts discovered in the twentieth century, Igbo art is generally known for various types of masquerade masks and outfits symbolizing people, animals, or abstract images. The New Yam Festival is an annual cultural festival held at the end of the rainy season in early August to symbolize the conclusion of a harvest and the beginning of the next work cycle. The celebration ties individual Igbo communities together as essentially agrarian and dependent on yam.

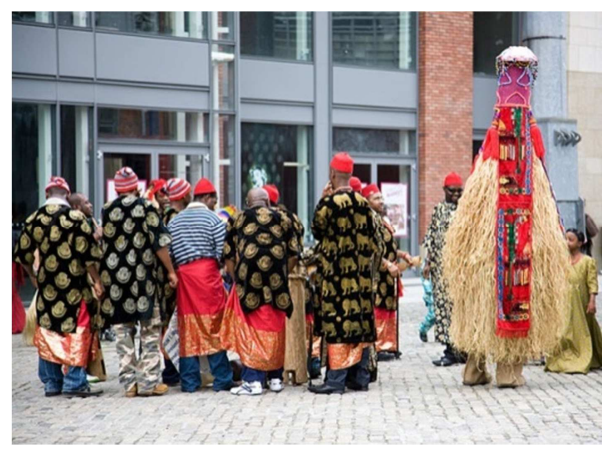

Source: A Courtesy Picture.

Figures 2. An Igbo Dance on Yam festival Celebration.

New Yam Festival: On the right, a participant wears an elaborate mask and headdress with attire made of raffia. The festival in this photograph was organized by Igbo society group.

f) Subject from Colors and Symbols

The collected representations illustrating a subject. Colors and Meaning. There are different color variations for the kente, each color has different meanings. Here are some examples: Black: maturation, White: purification, Yellow: preciousness, Blue: peacefulness, Red: bloodshed.

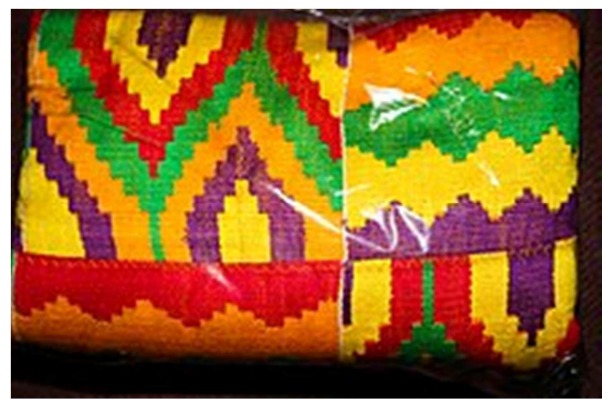

Source: Main articles: Akan art and Adinkra symbols, See also: Akrafena.

Figures 3. Colors Representation.

A set of specified or traditional symbolic forms associated with the subject or theme of a stylized work of art. A treatise or books dealing with iconography. This will refers to the numbers of writings that existed in the ancient, modern and contemporary times. The passing of time indicates development and progress. [19]

\subsubsection{Evolutionary Meaning of Iconography}

The iconography of an architecture, sculpture, painting and writing is the imaginary in it. The term comes from the Greek word icon-meaning image. An icon was originally a picture of Christ on a panel used as an object of devotion in the orthodox Greek Church from at least the $17^{\text {th }}$ century on. Hence, the term icon has come to be attached to any object or image that is outstanding or has a special meaning attached to it. An iconography is a particular range or system of types of images used by an artist or artist covey particular meanings. For example in Christian religious painting, there is an iconography of images such as the lamb, which represents Christ or the dove, which represents the Holy Spirit. In the iconography of classical myth however, the presence of a dove would suggest that any woman also present would be the goddess Aphrodite or Venus, so the meanings of particular images can depend on context. In the $18^{\text {th }}$ century, William Blake invented a complex personal iconography to illustrate his vision of man and God, and much scholarship has been devoted to interpret it. In the $20^{\text {th }}$ century the iconography of Picasso work is mostly autobiographical, while Joseph Beuys developed an iconography of substances such as felt fat and honey, to express his ideals about life and society. Iconography (or iconology) is also the academic discipline of the study of images in art and their meaning. [13]

\subsubsection{Origin of Iconography}

The origin of iconography in the wide sense belongs to prehistoric times. The first attempts to represent human being by images were made in Ancient Egypt. A higher stage of development is shown by the ancient Egyptian sculptures, particularly those of the pharoanic period, among which, along with many crude expressions of exaggerated phantasy, the are also found in Egyptian sculpture, which in all times appears closely connected with architecture. As usual in primitive art, the works of the earliest or mephitic period until 3500, Before Christ (BC) are distinguished by originality and naturalism, while in the later period the human figure was molded in accordance with an unchangeable canon or type from which only the countenances show any deviation. [36] The sculptures of the later period are principally relief, produced by incised outlines and slight modeling; status also occurs, but groups are very rare. With the eleventh dynasty of Egyptian Kings about $3500 \mathrm{BC}$ the size of the figure was increased to colossal proportions, but as they were all executed according to the traditionally type, sculpture gradually declined. No important revival occurred because Egyptian sculptures as were gradually absorbed by the all-embracing Hellenistic art. Besides representations of religious scenes and episodes of court life those depicting the daily life of the people were also popular. These were diction by the belief of the Egyptian that such representations were pleasing to the dead and that they beautifies their life in the other world. [37] 


\section{Result}

\subsection{Architecture and Sculpture in the Sub Saharan Region}

\subsubsection{Architecture}

The architecture of Africa like other aspects of culture of Africa is exceptionally diverse. Many ethno-linguistic groups throughout the history of Africa have had their own architectural traditions. In some cases, broader styles can be identified such as the Sahelian architecture of an area of West Africa. The great pyramids of Giza are regarded as one of the greatest architectural feasts of all times, and one of the seven wonders of the "Ancient World. [19]

As with most architectural tradition elsewhere, Sub Sahara African architecture has been subjected to numerous external influences from earliest periods for which evidence is available. Ancient Egyptian architecture, for example, reveals strong influence from ancient South-West Asian traditions, more recently, Islamic tradition leading to the creation of the Swahili architectural style. Western architecture has also had an impact on coastal areas since the late $15^{\text {th }}$ century, and is now an important source to many large buildings, particularly in major cities. [29]

\subsubsection{Early Architecture}

The Kushite pyramids, influenced by Egyptian architecture in the $11^{\text {th }}$ century $\mathrm{BC}$ probably the most famous class of structures in Africa, the pyramids of Egypt remain of the world's greatest early architectural achievements, if limited in practical scope and originating from a purely funerary context. Egyptian architectural tradition also saw a vast temple complexes and buildings.

The Nubian pyramids of the first millennium BC were subsequently influences by their late third millennium BC predecessor in Egypt. By the Meriotic period, houses were of two rooms, forming large complexes. Notable buildings include the Meriotic Western Palace of Farris, built of sundried bricks.

Little is known of ancient architecture South and West of Sahara. The best-known building of the period is the fifth or sixth century BC multi-storey tower at Yaha in Ethiopia, believed to have been the capital. Harder to date are the monoliths around the Cross River, which they have geometric or human designs. The vast number of Senegambia stone circles also evident an emerging architecture.

\subsubsection{Medieval Architecture [30]}

The conical tower inside the Great Enclosure in Great Zimbabwe, a medieval city built by a prosperous culture. Great Zimbabwe is the largest medieval city in the SubSaharan Africa. Great Zimbabwe was constructed and expanded for more than 300 years in a local style that eschewed rectilinearly for housing curves. Neither the first nor the last of some 300 complexes located on the Zimbabwean plateau, Great Zimbabwe is set apart by it terrifies scale of structure. Its most formidable edifice, commonly referred to as the Great Enclosure, has dressed stones walls as high as 36 feet extending approximately 820 feet, making it the largest ancient structure south of the Sahara desert. Houses within the enclosure were circular and constructed of wattle and doub, with conical thatched roofs. [29]

The Great Mosque of Jeanne in Mali, first built in the $13^{\text {th }}$ century and reconstructed in 1906-1909, is the largest clay building in the world. Ethiopia was the home to several architectural styles. Axumite architecture developed further around Lalibela saw the apotheosis of monolithic architecture. Tombs and entire churches were carved out of single blocks of rocks, in a style, which showed the influence of southwestern Arabia, among the most spectacular oneroom stone structure or story round houses of sandstone with basalt foundations. The arrival of the Portuguese sellers and Jesuit missionaries in the $16^{\text {th }}$ and $17^{\text {th }}$ centuries saw the development of the castles of Gondar and appreciated it.

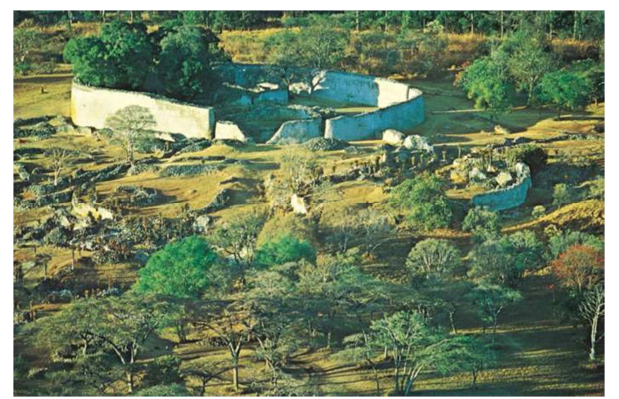

Figure 4. Characteristic of architecture elsewhere in Sub Sahara Africa.

Source: An Aeriel View of Ruins of Curves Construction at Great Zimbabwe [31].

Furthermore, the growth of Muslims influence and the development of ports saw the birth of Swahili architecture. An early example is the Palace of Husuni Kubwa lying West of Kilwa, built about 1245 years ago. As with many other early Swahili buildings coral was the main construction material and the roofs consist of corals or timbers. Contrastingly, the palace of Kilwa was a two-story tower, in a walled enclosure. Other notable structures of the period included the pillars of Malindi and Mnarani in Kenya and elsewhere originally built from coral but later from stone. Later examples include Zanzibar's stone town, with its famous carved doors and Kilwa's Great mosque. [30]

The Islamic conquest South of Sahara, Islamic influence was a major contributing factor to architectural development from the time of the kingdom of Ghana at KumbiSaleh, locals lived in domed huts but traders had stones houses. Sahelian architecture initially grew from two cities of Djenne and Timbuktu. The Sankore Mosque in Timbuktu constructed from mud on timber, was similar in style to the Great Mosque in Djenne. The rise of kingdoms in West African coastal region produced architecture, which drew instead on indigenous tradition, utilising wood. The famed Benin City, destroyed by the Punitive Expedition was a large complex of homes in coursed mud, with hipped roofs of shingles or palm leaves. The palace had a sequence of ceremonial rooms and 
was decorated with brass plaques.

Early or other embellishing was gradually accreted with the style inspiring later buildings such as Lamu Fort and the stone palace of Kumasi. Ashanti architecture is perhaps best known from the reconstruction at Kumasi. It key features are courtyard based buildings and walls with striking relief in mud plasters brightly painted. An example of a shrine can be seen at Bawjiwiasi in Ghana. Four rectangular rooms constructed from wattle and daub, lie around a courtyard. Animal designs mark the walls and palm leaves cut to tired shape provide the roof. The Yoruba surrounded their settlement with massive mud walls. Their building has a similar plan to the Ashanti Shrines but with verandas around the court. The walls were of puddle mud and palm oil.

\subsubsection{Modern Architecture [28]}

By the late $19^{\text {th }}$ century, most building became fashionable. In the $20^{\text {th }}$ century, from the time colonial buildings went across the continent of Africa, the Africans put up some important and noble structures. After 1945, Maxwell Fry and Jane Drew extended their works on British schools into Ghana and designed the University of Ibadan. The European took African culture, developed it and sent it back. Furthermore, the reconstruction of Algiers offered more opportunities, with Algiers Cathedral and Universities by Oscar Niemeyer, KenzoTange, Zwietel and Skidmore, Owings and Merrill. But modern architecture in this sense largely remained the preserve of European architects until the 1960s, one notable exception being "Le Groupe Transvaal" in South Africa, who built homes inspired by Walter Groupius and Le Gorbusier. [32]

A number of new cities were build following the end of colonialism, while others were greatly expanded. Perhaps the best-known example is that of Abidjan, Victorian andBanana Islands in Nigeria, where the majority of buildings were still designed by high profile.

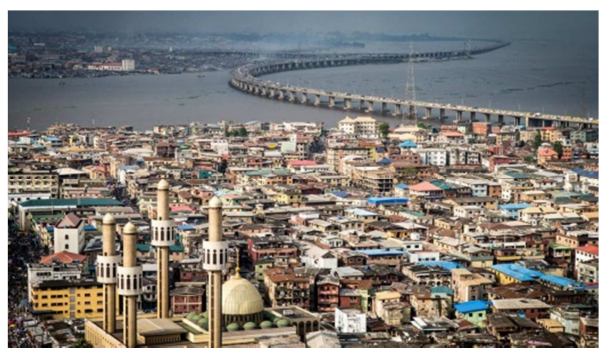

Source: Author Courtesy Picture.

Figure 5. Banana Island in Sub Sahara Nigeria.

African architects. In Yamoussoukro, the Basilica of our Lady of Peace of Yamoussoukro is an example of a desire for monumentality in these new cities, but Arch 22 in the old Gambian capital of Banjul displays the same bravado. Experimental designs have also appeared, most notably the east gate Centre, Harare in Zimbabwe. With an advanced form of natural air conditioning, this building was design to respond precisely to Harare climates and needs, rather than import less suitable designs. Neo-Vernacular architecture continues, for instance with the great Mosque of Nioro or New Gourna. Other notable structure of recent years has been some of the world's largest dams. The Aswan High Dam and Akosombo Dam hold back the world's largest reservoirs. [32, 31]
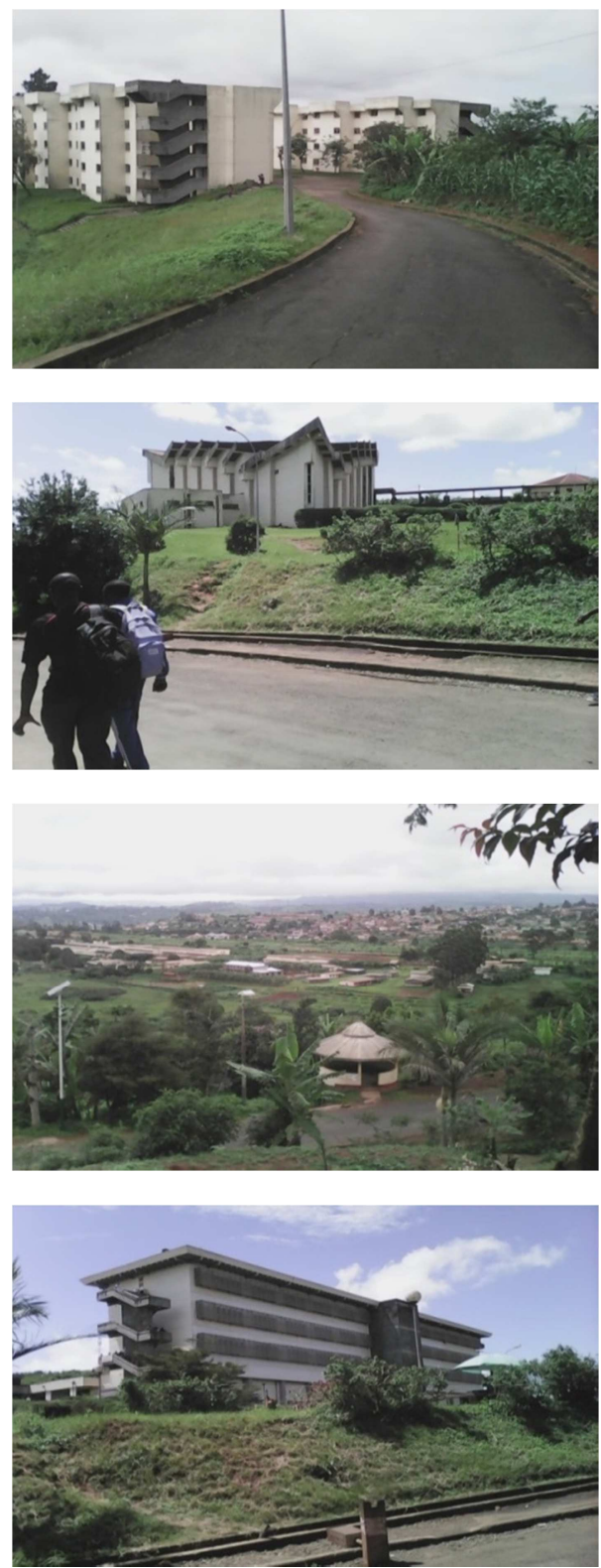

Source: Authors Courtesy picture.

Figure 6. The University of Dschang.

In recent years, there has also been renewed bridge building in many nations, such bridges of renovation is that of the Ekok-Ikom a frontier between Cameroon and Nigeria, that between Bonaberi-Ronde point Deidobridge of Douala across the Wouri river, while the trans-Gabon Railway is perhaps the last of the great Railway to be constructed.

The commemoration of the library of Alexandria, once the largest library's architecture is ultramodern and very nontraditional. In Cameroon, the University of Dschang was partly constructed by a Cameroonian construction company 
and American assistance. University of Douala, Buea and Yaounde follow suit. The Canadian government has constructed comfortable Government Technical High School as aids in some parts of Cameroon such as southwest in Kumba to Limbe, Northwest in Nkwen, at Ngoundere, Bafoussamand others. The Japanese has also constructed recently some primary schools in some part of the country. Hence, architecture in modern Sub-Saharan region has undergone several metamorphoses from within and from outside skills.
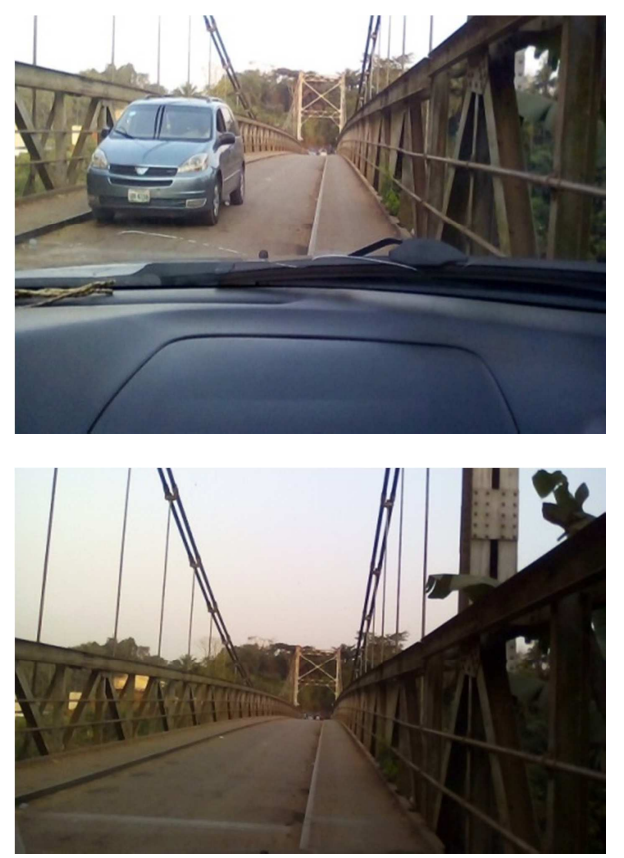

Source: Authors Courtesy Picture.

Figure 7. The Ekok-Ikom Bridge at the Frontier between Cameroon and Nigeria.

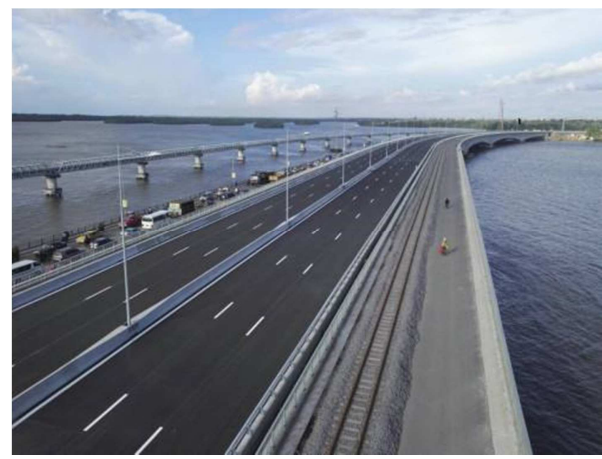

Source: Authors Courtesy picture.

Figure 8. Bonaberi Bridge Across the Wouri River.

\subsection{Sculpture}

Sculpture is generally considered Africa's greatest achievement in the visual art, but although sculpture is found in many parts of Africa, this medium of expression occurs with the greatest frequency in western and central Africa. This majority of sculptures are of wood, but objects are also made in metals, stone terra cotta, mud, beadwork, ivory and other materials. The terra cotta sculpture associated with the Nok culture represent the earliest known sculpture found in Sub-Saharan Africa and seems to have paved the way for the tradition of superb portrait, terra cottas and bronzes later developed at the holy city of life in Western Nigeria. In addition to mask examples of sculpture, include figural representations such as power figures and the statues of ancestors and kings as well as objects of daily use such as cups and boxes.

\subsubsection{Nok Culture Nigeria}

The male Nok head sculpture was found in Nigeria SubSaharan region. Nigeria is part of the central Sudanic stylistic region. Nigeria is unusual in that modern day inhabitants settle there either very early in its history or adapted to the long established traditions they found there. The first objects connected to the early Nok culture were discovered on the site of a tin mine. They were identified as Nok by the archaeologist BenardFagg in 1943. Radiocarbon dating has placed the original pieces to between $500 \mathrm{BC}$ and $\mathrm{AD}$ (After Christ). Terra cotta sculpture from $600 \mathrm{BC}$ to unearthed over a 300-miles stretch of uplands in the southern part of the region.

The Nok tradition represent the earliest known sculpture yet found in Sub-Saharan Africa and seems to have paved the way for the tradition of superb portrait terra cottas and bronzes that later developed at the holy city in Western Nigeria. The art of life in turn inspired and stimulated the later Benin and Yoruba art forms. The pieces of sculpture associated with the Nok culture seem to represent a mature, developed style. They show some of the plastic traces of tentativeness usually associated with a beginning phase of an artistic tradition but rather more a stylistic unity characteristic of an established one.

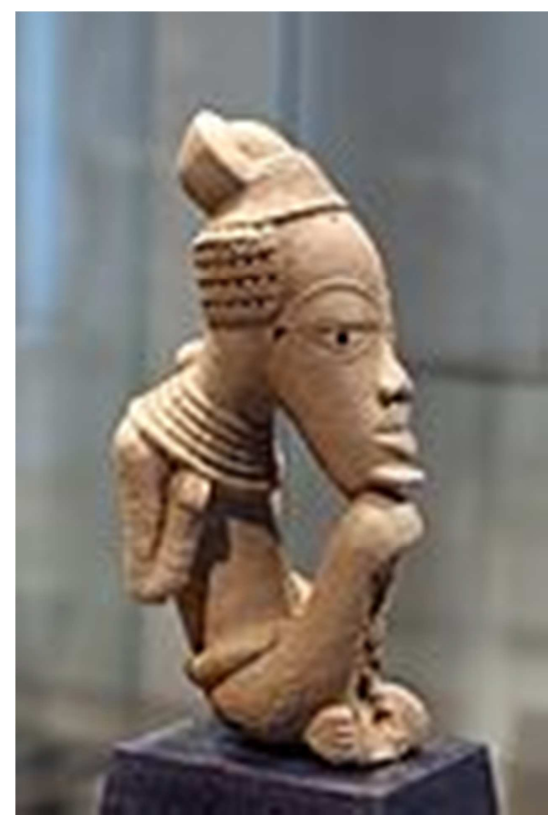

Source: Authors Courtesy Picture.

Figure 9. The Nok Head in Nigeria (Nok Culture). 
The styles to be found in the art of the Nok swings between an almost abstract stylization to that of more naturalistic mode. This head exhibit naturalism but in a minimal fashion. It is the earliest example in Sub-Saharan Africa of human figural sculpture on a scale approaching life size. From the nature of their breaks near the neck, many of the head seem to have been part of or destined to be part of a body. [27] Looking to later cultures such as the Benin where naturalistic modeled bronze heads were part of royal ancestral altars, it could be hypothesized that these heads might have been part of the art objects connected with royalty and the worship of the ancestors. Of now, there is insufficient evidence to do more than hypothesize from later culture that developed in Nigeria. [4]

\subsubsection{Lesson plan for Nok Head}

Clay figures unearthed in the mid-twentieth century provide a cultural link even though their origins are obscure. In Nok, Nigeria certain terra cotta heads-named after the small village on a Northern plateau in Western Africarepresent the earliest known sculpture, sculpted and used from $600 \mathrm{BC}$ to $200 \mathrm{AD}$. The grade level is six grades, the visuals: slide of Nok Head, three slides of Kenya-Maasai taken from the art of Africa by Shirley Glubok. Material: modeling clay-earthen gray or terra cotta, clay tools, paper bowl and Antique Glaze-reddish-brown tones. [3]

\section{Preparation and subject integration}

The Maasai tribe in Kenya is compared with Nigerian, Liberian and tribes within the Central Sudanic stylistic region. Tribal features, custom and beliefs will be learned as plastic visual Art is integrated with social studies. [33]

Some artistic practices include the use of bright colours, especially red, oranges and blue were used by the Maasai to cover their boulies during tribal ceremonies, as they portrayed the importance of contrasting themselves with the brown tones earth. Bafut is also good at artistic works, it is a deport of artistic fabrics or works of different kind; Jujumask, hand-rattle, Cow-horn cup, fibers bags, baskets, calabash-rattles and wood and Iron-gongs. This is quite a good example of handicraft in Bafut found in TheMezam Division, North West Region of Cameroon. [25, 22]

The Yoruba often decorate doors and walls with beautiful carved wooden relief. Wild animals, human figures and mystical beings are popular subjects. Like in the Cameroon Grassfields some carved heads of Juju are displaced in Museums like the Great Head of Diesis Representation with a polished wood Head Mask used during the Fon-dance "Mbin-fo" a festival that takes place annually. Some ceremonial masks weigh as much as eighty pounds while others are usually worn by women and thrown away following a ceremony. Others are sculpted with great care. At present, the origin of theNok culture or links from this to later tribal societies has not been discovered. Terra cotta heads were discovered in 1944 during mining operations. These clay figurines have been buried centuries before and are the oldest known pieces of Africa sculpture. The male heads dates to shortly after the time of Christ. It can only be assumed that the head portrays an important and actual person within the Nok society, because of the sensitivity, modeled clay elaborated headdress and the inclusion of ornament.

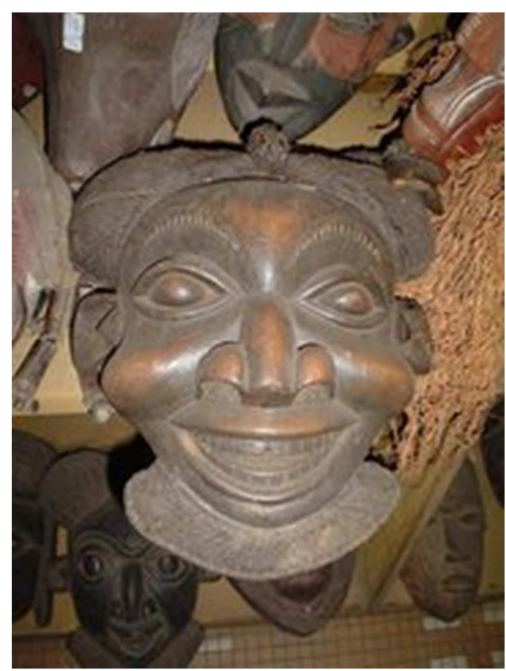

Source: Authors Courtesy Picture.

Figure 10. Carved Heads of Juju in the Bafut Museum.

In other civilisation such ancient terra cotta were used as tomb furniture and part of public or domestic shrines. These sculptures paved the way for the tradition of portrait terra cottas and bronze that later developed in the city of life in Western Nigeria. The art of Ife inspired and stimulated the later Benin and Yoruba art forms. If terra cotta clay is used glazing is not necessary, otherwise earthen clay can be with a flat reddish-brown finish Kiln firing will complete the procedure. [3]

\section{Procedure}

The procedure goes as follows; after wedging clay, roll and hand build a clay face fashioned after the style of a Nok head sculpture, form, roll and symmetrically shape the clay over the outside of a paper bowl, evenly cutting away the outside edges keep the sculpture from dying out by spraying it with water and keeping it covered with plastic between working sessions. Score the damp clay and use slip to facial features, a headdress, or decorative ornaments. Allow the clay to dry and kiln fire as green was. Use fine sand paper to smooth away rough edges. Using a reddish brown antique glaze, or leave the terra cotta head as is. [3]

\section{Result}

Thoroughly dry the sculptural fabric and apply a kiln fire for it to give the artistic plastic nature hence the sculpture at cone. [3]

\subsection{Painting and Writing in Sub-Saharan Region}

\subsubsection{Painting}

Painting is the art of using colors for decoration. This could be seen as fibers bag fabricators or pleating usually soaked material that came out of Raffia Branches from the leaves. It is deepen in to some prepared liquid paint before plaiting the bag using beautiful decorative colors thread. Sub- 
Saharan paintings have much to reckon with. Africa has a vast heritage of painting intended from ancient Egypt. Due to it mutation and spread, Sub-Saharan region also benefited of it. We cannot forget the Shaka Zulu wall and skin paintings during dancing festival in South Africa. African art of painting has three main factors that have help to preserve it validity; belief systems, inaccessibility and secrecy. [7]

\subsubsection{Location of Painting}

The sites are generally located in lands and comprise rock shelters, caves and smooth open rock surfaces. Most of the shelters with paintings are high on bush-covered hillsides, facing or overlooking plains, valleys or rivers. The painters seem to have preferred such locations because they commanded a wide view of the plains and of immediate surrounding areas, which enabled them to watch game and sometimes, perhaps, hostile warring peoples. Hilltops were also suitable for camping especially during the wet seasons when the low-lying plains would be flooded. [9] Most sides were accessible only to special groups of people at particular times and there were strict taboos against visiting, cutting trees, herding or even collecting fire wood from them. Most sides were inaccessible to villagers and people who did manage to reach them were deterred by taboos from vandalizing the art. Most important of all, some sites were usually known only to elders and practitioners of rituals who tried to keep their location secret. But as time went on, some changes were experienced. [8]

\subsubsection{Location Mutation (Changes)}

Unfortunately for the location of groups, the situation has drastically changed as time passes or progresses. The belief system that guarded the site has broken down and is no longer respected. Population growth has stepped up demands on land for agricultural use and since taboos no longer act as a deterrent, people encroach on the site with impunity. Nowadays, painting grounds are found everywhere in the towns, cities and villages and even behind houses. Offices of painting are dotted everywhere in sub-Saharan region like Cameroon, Nigeria and others. [4]

\subsubsection{Examples of Painting}

Painted screens depicting ancestors decorate small shrines houses of the Mambila. The painting portrays male and female under a cosmic canopy, with sun, moon and a rainbow. A triangle seen between some two figures is a symbol of the village compound and universe and represents the belief that each man and woman serves as a link between the spiritual and temporal worlds. The traditional dress has some decorations with coloured or painted threads that give the dress it beauty with some dotted spots within and around the black material used. [4] We can also see a queen mother portrait well painted in the sub-Saharan region in Africa thus the colour red shows the seriousness and hard work of the Queen mother as he direct and advice the king or Fon on vital issues of the Chiefdom or kingdom. She is known to be one of the advisers of the King. Her ears are wild open and a listening storage, the are yellowish bright and wide or large which give her the potentiality to see all and make decisions, The head is reddish and the mouth hence as she reasons and speak sense coming from within her good heart towards the indigenes. [33]

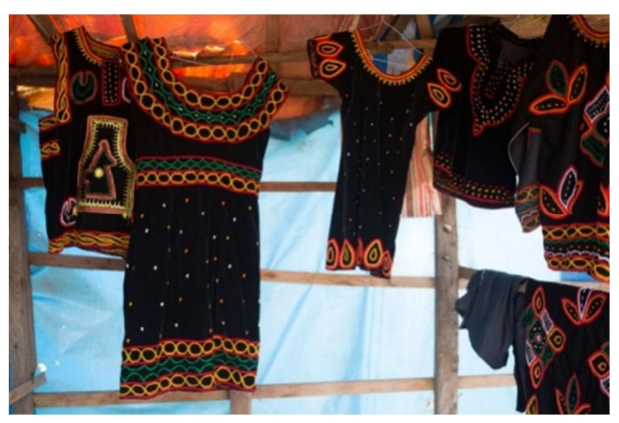

Figure 11. Ceremonial Grassfields Traditional Dress.

Source: Rachels Field notes, The Art of creating Traditional Northwest Wear, October $17^{\text {th }} 2016$. In blograchelchaleof.com/the-art-art-creatingtraditional-northernwest-[34].

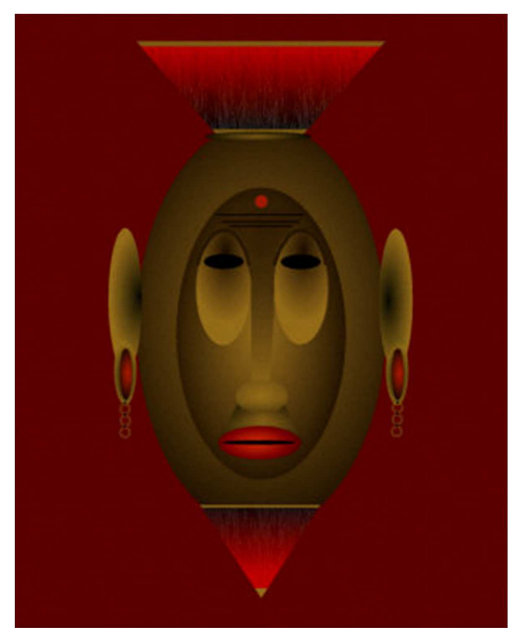

Figure 12. Painting of a Queen Mother in Sub-Saharan Africa.

Source: Painting In https://www.art.com/products/p1793882232sa74225736/rich-lapenna [40].

Another example is the print textiles produced in Africa for the market in 1920 to 1950 as a cheaper substitute for socall "Dutch Wax" resin-result prints. Although they of lower quality and the design was only on the face, they had one distinct advantage which soon open up a new range of decorative possibilities and hence a novel social role. Unlike wax prints, the technology of fancy prints allowed for the reproduction of photographic images. Very quickly, the technique was adopted to produce what have become known as commemorative cloths. At first, these were for funerary ceremonies in the Gold Coast (present day Ghana). African company shows a woman, presumably a wealthy market trader, named only as "Mammy" while another shows a deceased Ewe Chief. [21] Other cloths commemorated specific events such as a visit to the Gold Coast by the Prince of Wales. [2]

Furthermore, another example in many parts of Africa is, there is a long tradition of leaders, chief and "big" men and 
women distributing cloths to their followers. The new leaders of independent Africa in the 1960s were quick to adopt the medium of fancy printed cloths to promote themselves within the expectations framed by these traditions. Cloths were printed at government expense and distributed free or at subsidized prices via market, women either to promote specific events, political campaigns or as part of a more general policy of self-promotion. Wearing such a cloth was often advisable as an outwardly visible expression of allegiance to be ruling powers whatever the wearer's actual sentiments.

More so, the are several cloths displayed, are part of a private collection focused on Francophone African Countries. No doubt interesting parallels and differences could be found in a comparative study of commemorative cloths from other areas of Africa.

1. Writings

Writing actually started in ancient Egypt with the notion of pictogram or picture representation. Someone who wants to say, "see that animal" will surely represent it with some drawing. An eye geared or focus toward an animal. The Papyrus became instrument of figure presentation, gradually, the Egyptians writing known as hieroglyphics developed. (the Shumum of the Bamoun kingdom also developed involving others like the Senegalese wolof and kenyan Swahilis). [34]

\section{Egyptian-Hieroglyphics}

Hieroglyphics in Egyptology remains a very pertinent source in history as it implies. Africa historian had relied on very close materials documents or facts and this writing has spread to almost every part of Africa. This writing has almost enhanced the spread of pharaonic civilization. The Egyptians Hieroglyphics permit the understanding of very rich and peasant literature, which is of great importance, even for the Africans of today. Some example focuses on the writing on funeral tombs, monumental writing, administrative art, religious hymns, philosophical works, mathematics and medicinal treatments. Furthermore, the Hieroglyphics has actually paved the way of critical of ancient Egypt; hence, on marine teachings, economic relations between Nile and Red sea, the introduction of the study of Ancient Egypt in African. Universities permit a renewal and confirm our love for African. This writing has also helped the Europeans to realise their Hellenistic civilisation. Hence, the papyrus is now conserved in Europe specifically in France. There also exist historical encyclopedias (jurisdictional). [34]

\section{The Bamoun-Shumum}

The Shumumwriting was introduced in Bamoun by Njoya as a means of communication and the spread of the Moslem religion. This was also a medium to Islamisation of the kingdom of Njoya. It alphabet was thirty in number. The Shumum writing has some resemblance with the Egyptian writings. It has greatly help to spread the Bamoun culture to other parts of Cameroon like in Banso and Bali-Kumbat. Due to this writing, written on the tomb of all the past sultans has enable historian to know the number of sultans that has ruled Bamoun kingdom, hence their duration, age and philosophy.
EngelbertMveng made us to understand sultan Njoya was a brave and powerful from his descriptive countenance. [17]

4. The other writings

These include the Wolof, Swahili, Demotic and Meroitic writings. These writings have done great to Africa history. Like with the Wolof, Cheikh Anta Diop evoked this writing or language to resemble that of Ancient Egypt as applied to the other writings. The Swahili from the East of Africa has brought or contributed to African civilisation. The study of an ancient writing is like a journey to the past where we see ourselves in the century past. [34]

\section{Discussion}

\subsection{Importance of Iconography in Sub-Saharan Africa}

\subsubsection{Architecture and Sculpture}

Monumental temple architecture is rare in Sub-Saharan Africa, for in animist religions spirits may reside in trees, carved figures, or small, simple shrines. Shrine rooms containing objects and like the shrine house of the Asante, with its rooms for an orchestra and the officiating priest, to the dwelling compound. A more notable structure is the elaborate mbari house of the Owerri Igbo of Nigeria. It has a large open-sided shelter, square in plan, it houses many lifesize painted figures sculpted in mud and intended to placate the figure of Ala, the earth goddess, who is supported by deities of thunder and water.

The remaining sculptures - often witty - are of craftsmen, officials, Europeans, animals, and imaginary beasts. Because the process of building is regarded as a sacred act, mbari houses, which once took years to build, were left to decay, and new ones were constructed rather than old ones maintained. Contemporary mbari structures are formed from cement, and the symbolism of decay and renewal has therefore been lost.

\subsubsection{Contribution of Architecture to History}

Architecture has greatly helped in the building of mansions and story buildings. Hence the Egyptians pyramids had staircase, which now are represented in large African buildings like the unity Palace and General assembly, Yaounde. In addition, in the Bamileke regions, house roofing takes the form of the Egyptians pyramids thus showing the important of Egyptians architecture in history hence portraying this similarity. [18]

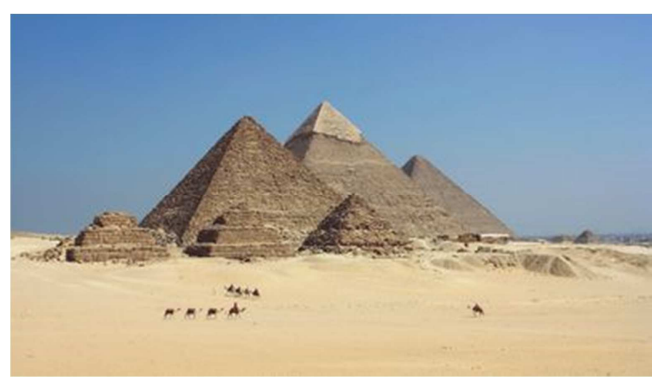




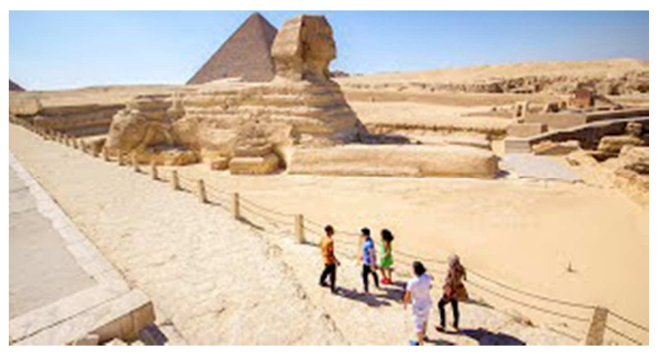

Figure 13. The Pyramids of Gizeh.

Source: Cheikh AntaDiop, Civilisation ou Barbarie, Edition, Présence Africaine, Paris, 1981. (Cover page) [6].

Even the pyramids houses and the Moslem mosques also foster or shows prove of African cultural history. It has greatly led to historical development.

\subsubsection{Contributions of Sculpture to History}

Sculpture has played a great role in history. Important figures are being represented with carving objects or statues, such as that of Njoya in Bamoun kingdom, some chiefs in the Bamileke region and head of states in Africa. They can be seen and known through pictures centuries upon centuries. The Nok head is still an example which was carved in Nigeria, hence the plastic artistic Nok civilization. He is still remembered thus has contributed to history. [37, 38]

\subsection{Other Importance}

\subsubsection{Writing and Painting}

The are different types of adopted writing we know today in sub-Saharan Africa that developed as a result of the Egyptian writing. Their importance are several and vary hence interpreting and give meaningfulness to the societies in the light of expressionism and impressionism.

Alexis Preller, for instance, created fantastically detailed canvases influenced by the European surrealists of and within the modern era. Beginning in the late 1940s, Preller painted African scenes and themes such as The Kraal and Hieratic Women, but these were not realistic portraits of African life: instead, they were reinvented by Preller's startling visual imagination. Over that time, they created a vast body of meaningful art on the walls of caves and rock shelters - the largest and most concentrated group of rock paintings in subSaharan Africa. This rich collection prompted Unesco to inscribe the Drakensberg as a mixed natural and cultural world heritage site in the contemporary time. The paintings, Unesco said, "represent the spiritual life of the San people" and are "outstanding both in quality and diversity of subject".

\subsubsection{Contribution of Writing to History}

Writing has played a dominant role in the domain of communication in Africa. It actually started in Ancient Egypt and has spread with some modifications, improved in the entire continent. In the Sub Saharan Africa we can now give an account of many different kind or forms of writings emanating and coming from different areas: The Egyptian, Wolof, Swahili, Arab, French, English, Bamum 'Shumum' writings. All these writings have help to facilitate discussions amongst men of good will to teach and bring or give solutions to some problems. This writing has made the world to be a global village and globalisation has been enhancing to a wider dimension as a result to writing. [34] Actually in the world today, the exist several school of thoughts where these writings are written and deposited for research, for example we have the school of Annals in Senegal, and great libraries and research centers doted in the Sub Saharan Africa like that of Darker and University of Alexander in Senegal and Egypt respectively. Also, these assorted writings has help developed and improve on the mind and intelligence of the African and worldly knowledge across some number of cultures. [32] It should be noted that another iconographic aspect that has enormous importance is painting. [35]

\subsubsection{Contribution of Painting to History}

Due to painting, we could know or learn that, some Egyptian pharaohs were black and some white, painted on walls of houses and besides tombs in pyramids. Painting of houses shows some beauties that existed in Ancient Egypt. They painted their shrines and the houses of pharaoh including some noble buildings. This has actually spread the Egyptians civilization to other parts of Africa and Europe. Now, there are important structures that carry good paintings. [10] The textile work of head of states of Africa that carries important and good colouring attraction expressing their nature of governance like Abdou Diouf, the democratic president of Senegal 1981-2000. Some other African head of state carry other colours in their textile material showing their objectives thus contributing to history. The yellow lion or Leopard and traditional blue dress, paintings on walls go ahead to symbolize the braveness of the palaces contributing to history.

\section{Conclusion}

In the nutshell, Some Definitions, Evolutionary Meaning and Origin of Iconography in Sub-Saharan Africa, Architecture and Sculpture in the Sub Saharan Region, Painting and Writing in Sub-Saharan Region, Importance of Iconography in Sub-Saharan Africa has been examine. Iconography South of the Sahara remain a very pertinent source in history as implies historical archaeology by an interpretation of Egyptians architecture, sculpture, painting and writing which has greatly improved on the history of sub-Saharan region and the world at large. [12] The strong and deep spread of the Pharaonic civilization has been propagated without any rupture (exact-copy). Africa, according to some historians such as Cheikh Anta Diop who said, these are the black African energetically resources. The are used by Africans themselves not for the creation of complimentary Industries like those of Europe, but for the transformation of raw material presently in the continent, would permit to make Africa a terrestrial or earthly paradise inpage, sixty six. [6] This is taken from one of the works of Cheikh Anta Diop. Les Fondements culturels, techniques et Industriels d'un future Etat Fédéral 
d'Afrique Noire. Hence, Cheikh Anta Diop made us to know that Africans hasresources and nothing is remain to be created, therefore, it is just for the Africans to transform these primary materials in the continent into industries and make Sub-Sahara Africa a paradise. [7] Hence, architecture, sculpture, painting, writing are some of the Iconography values that the Sub-Saharan Africans should also duel on and improved on them to give to the Africans a valuable and tangible history, not forgetting some aspects like images of POWER, Lion or Leopard as Authority representation, the use of paints in materials; such as African president in printed Fabrics; like Abdou Diouf, president of Senegal, thus some of these values goes ahead to contribute to our history. [1] What measure can SubSaharaAfricans use to further as a means of improving their Iconography statue?

\section{References}

[1] Appadurai A, Modernity at Large: Cultural Dimensions of Globalization. Minneapolis: University of Minnesota Press. 1996.

[2] Arkell. A J, History of the Sudan: From the earliest Times to 1821, London, the Athlone Press, 1955.

[3] Basil Davidson, A History of West Africa, 1000-1800. London, Longman, 1965.

[4] Basil Davidson, The African Past, New York, Grosset and Dunlap, 1967.

[5] Chancellor Williams, The Destruction of Black Civilization, Chicago, Third World Press, 1974.

[6] Cheikh Anta Diop, Civilisation ou Barbarie, Edition Présence Africaine, Paris, 1981.

[7] Cheikh Anta Diop: les Fondements culturels, techniques et industriels d'un futur état Fédéral d'Africaine Noir, Paris, Présence Africaines, 1960.

[8] Argenti N, "Air Youth: Performance, Violence and the State in Cameroon." Royal Anthropological Institute of Great Britain and Ireland Journal 4: 1998: pp. 753-782.

[9] Argenti N, "Kesum Body and Places of the Gods: The Politics of Children Masking and Second World Realities in Oku, Cameroon." The Journal of the Royal Anthropological Institute 7, 2001, pp. 67-94.

[10] Clifford J, The Predicament of Culture: Twentieth- Century Ethnography, Literature and Art. Harvard University Press. Cambridge, Massachusetts. 1988.

[11] Daniel C. Bach, Le Nigeria Contemporain, Editions du (CNRS) Edition Du Centre National De La Recherche Scientifique, Paris Orstom, 1986.

[12] EbwaEbwa Serge Michael,«Patrimoine Culturel Mbo et Culture Occidentales: Le cas de Mbouroukou (1906-2010)» Master en Histoire, Université De Dschang, Dschang, 2013.

[13] Forni S, "Containers of Life: Pottery and Social Relations in the Grassfields, Cameroon.” In African Arts 40, pp. 42-53.

[14] Fouelefac Kana Celestine Colette et Ladislas Nzesse,
Patrimoine Culturel Africain, Matériau Pour L'Histoire, Outil de Développement, L'Harmattan Cameroun, 2017.

[15] Fubah M, "Title Cups and People: Relationships and Change in Grassfields Art.” In Anthropos 107, pp. 183-193.

[16] Fubah M, "The Changing Life of the Buffalo and Cow Horn and New Methods of Adaptation by Carvers and Patrons in the Grassfields, Cameroon.” In African Studies 73, 2014: pp. 41-57.

[17] Geary C, "Bamum Thrones and Stools." In African Arts 14, 1981: pp. 32-88.

[18] Gebauer P, Art of Cameroon. Portland Art Museum and Metropolitan Museum of Art. New York. 1979.

[19] Godelier M, The Enigma of the Gift. Polity Press. Cambridge. 1999.

[20] Hobsbawn E., Ranger T, The Invention of Tradition. Cambridge University Press. Cambridge. 1983.

[21] Jindram, "Christianity and the Proliferation of Ancestors: Changes in Hierarchy and Mortuary Ritualin the Cameroon Grassfields." In Africa: Journal of the International African Institute 75, 2005. pp. 356-377.

[22] Knöpfli H, Crafts and Technologies: Some Traditional Craftsmen of the Grassfields, Cameroon. Occasional Paper Number 107. British Museum, London. 1997.

[23] KolossH, World-View and Society in Oku, Cameroon. Dietrich Reimer. Berlin, 2000.

[24] Nicolas Agbohou, Le Franc CFA et L'euro Contre L'Afrique, Editions, Solidarité Mondiale, Paris, 1999.

[25] Simo Max Simo, "Architectural Evolution in the Bafut Fondom, Cameroon: 1889-1961," Master Theses, University of Dschang, Dschang, 2013.

[26] Yemmafouo Aristide, Urbanisation Et Espaces Périurbains En Afrique Subsaharienne Pratiques à L'Ouest-Cameroun. L'Harmattan Cameroun, 2013.

[27] Louvain-la-Neuve, History of sub Saharan Africa LHist 2610, 2017-2018 IN https://udouvain-be/encours2017.LHIST20610.htmlUc louvain (consulted 09/10/2019).

[28] Linda Poon, The Beauty of Africa's Traditional Architecture in one big Databas, CITYLAB, In https://www.citylab.com/design/2015/08/the-beauty-ofafrica.vernacular-architecture-c(consulted 09/10/2019).

[29] Paul Oliver, Janet B. Hess, Africa Architecture In https://www.britannica.com/art/Africa-architecture.18mars 2018 (consulted 09/10/2019).

[30] Peggy Wagner, Janet B Hess, Frank Willelt John Picton, Margret A Carey, Africa art, Visual ARTS, In Encyclopaedia Britannica, In https://www.britannica.com/art/African-art (consulted 10/10/2019).

[31] Classical Art of Sub-Saharan Africa In www.all.art.org/history.182html (consulted 10/10/2019).

[32] South African Icons, In Southafrica.co.za/major-Iconsattractions.html (consulted 10/10/2019).

[33] African art, In https://en.wikipedia.org/wiki/Africa-art (consulted 10/10/2019). 
[34] Ancient African Writings,-www.tanetar.org/writing.html (consulted 10/10/2019).

[35] Rachels Field notes, The Art of creating Traditional Northwest Wear, October 17th 2016.In blograchelchaleof.com/the-art-artcreating-traditional-northernwest.

[36] Interview with Pa Jean Doptsop at Dschang 1st May 2007, Age 82.

[37] Encyclopedias almanacs transcripts and maps, Iconography: Traditional African Iconography, (Updated Sep 06 2019).
[38] Iconography: Traditional Africa Iconography, In https: encyclopedia.com/environment/encyclopedas.almanacstrancripts.and-map (consulted 10/10/2019).

[39] Collaborative International Dictionary of ENGLISH V.O.48.

[40] Painting In https://www.art.com/products/p1793882232sa74225736/rich-lapenna. 